\title{
KEBIJAKAN PENDIDIKAN DI INDONESIA PADA MASA PANDEMI COVID-19 BESERTA DAMPAKNYA
}

\author{
Nur Alif Masitoh ${ }^{1}$ dan Heri Kurnia ${ }^{2}$ \\ ${ }^{1}$ Pendidikan Agama Islam, Institut Agama Islam Negeri Ponorogo \\ Jl. Pramuka No. 156, Ronowijayan, Siman, Tonatan, Kec. Ponorogo, Jawa Timur 63474 \\ ${ }^{2}$ Pendidikan Pancasila dan Kewarganegaraan, Universitas Cokroaminoto Yogyakarta \\ Jl. Perintis Kemerdekaan, Gambiran, Pandeyan, Umbulharjo, Kota Yogyakarta 55161 \\ ${ }^{1}$ Email: alifmasitoh01@gmail.com \\ ${ }^{2}$ Email Corresponding: herikurnia312@gmail.com
}

\begin{abstract}
ABSTRAK
Proses pembelajaran harus tetap dilaksanakan meskipun dalam situasi pandemi covid-19. Pandemi covid-19 telah mengubah tatanan proses pendidikan yang semula tatap muka di sekolah, menjadi tatap maya. Proses pembelajaran online mengharuskan pendidik untuk membuat model dan metode pembelajaran yang tepat dan tetap menyenangkan, agar materi pembelajaran dapat sampai kepada peserta didik dan dapat dipahami oleh peserta didik. Artikel ini bertujuan untuk mendeskripsikan mengenai kebijakan pendidikan di Indonesia pada masa pandemi covid-19 beserta dampaknya. Data pada artikel ini didapatkan melalui studi literatur atau penelitian kepustakaan dan studi kasus dengan mengumpulkan informasi dari berbagai sumber. Hasil penelitian menunjukkan bahwa kebijakan pendidikan pada masa pandemi covid-19 dilaksanakan dengan metode pembelajaran online dan pembelajaran luring yang dilaksanakan dengan protokol kesehatan yang ketat serta adanya pembagian waktu peserta didik untuk datang ke sekolah. Meskipun demikian, dampak dari pembelajaran daring ini sangat mempengaruhi siswa dan orang tua baik dari segi ekonomi dan psikologi.
\end{abstract}

Kata kuci: Kebijakan, Pendidikan, Masa Pandemi

\begin{abstract}
The learning process must continue to be carried out even in the covid-19 pandemic situation. The covid-19 pandemic has changed the order of the educational process, which was originally face-toface at school, to face-to-face virtual. The online learning process requires educators to create appropriate and fun learning models and methods, so that learning materials can reach students and can be understood by students. This article aims to describe education policies in Indonesia during the covid-19 pandemic and their impacts. The data in this article were obtained through literature studies or library research and case studies by collecting information from various sources. The results showed that education policies during the covid-19 pandemic were implemented using online learning methods and offline learning which were carried out with strict health protocols and there was a division of time for students to come to school. However, the impact of online learning greatly affects students and parents both in terms of economics and psychology.
\end{abstract}

Keywords: Policy, Education, Pandemic Period

\section{PENDAHULUAN}

Wabah virus corona (covid-19) yang telah melanda berbagai negara di dunia, memberikan dampak yang sangat besar bagi kehidupan, salah satunya bagi lembaga pendidikan (Abidin et al., 2020). Untuk mengurangi penyebaran virus corona (covid-19) ini, pemerintah memberlakukan aturan atau larangan adanya kerumunan, pembatasan sosial (social distancing), menjaga jarak aman (phsical distancing), memakai masker dan 
selalu mencuci tangan (Ameli et al., 2020). Proses pembelajaran harus tetap dilaksanakan meskipun dalam situasi pandemi covid-19, karena pendidikan merupakan kunci utama untuk menciptakan generasi-generasi unggul yang nantinya akan bersaing di dunia nyata (Anugrahana, 2020).

Kementerian pendidikan dan kebudayaan Indonesia (Kemendikbud, 2020), telah menetapkan pada Surat Edaran Menteri Pendidikan dan Kebudayaan Nomor 4 Tahun 2020 tentang Pelaksanaan Kebijakan Pendidikan dalam Masa Darurat Penyebaran Corona Virus Disease 2019 (covid-19) dan Surat Edaran Sektretaris Jenderal Kementerian Pendidikan dan Kebudayaan (Kemendikbud, 2020) Nomor 15 Tahun 2020 tentang Pedoman Penyelenggaraan Belajar dari Rumah dalam Masa Darurat Penyebaran Corona Virus Disease 2019 (covid-19).

Kondisi tersebut membuat masyarakat untuk tetap berada di rumah saja. Melakukan kegiatan belajar mengajar, bekerja dan beribadah dari rumah (Joharudin et al., 2020). Akibat adanya kebijakan tersebut, lembaga pendidikan mulai menghentikan pembelajaran tatap muka (Khasanah et al., 2020). Sebagai gantinya proses pembelajaran dilakukan secara dalam jaringan yang disebut dengan pembelajaran daring, yaitu metode belajar yang berlangsung secara jarak jauh menggunakan media jaringan medsos (Astini, 2020). Ada beberapa aplikasi yang dapat digunakan untuk membantu terlaksananya kegiatan belajar mengajar, di antaranya adalah Whatsapp Group, E-learning, Google Classroom, Zoom dan lain sebagainya.

Model pembelajaran yang dilakukan secara daring menuntut keterampilan dan inovasi dari guru dalam menggunakan teknologi (Astini, 2020). Proses pembelajaran online juga mengharuskan pendidik untuk membuat model dan metode pembelajaran yang tepat dan tetap menyenangkan, agar materi pembelajaran dapat sampai kepada peserta didik dan dapat dipahami oleh peserta didik (Yulianingsih et al., 2020). Peserta didik juga diharapkan mampu mengakses jaringan aplikasi yang digunakan dalam pembelajaran seperti Google Classroom, Zoom, dan beberapa aplikasi lainnya.

Menurut Wijayanti et al., (2020) pembelajaran daring, memberikan dampak positif bagi siswa, salah satunya adalah membuat siswa tidak merasakan tekanan dari teman sebaya seperti bullying yang biasa mereka alami saat pembelajaran luring, mungkin hal tersebut merupakan salah satu dampak positif dari adanya daring. Meskipun demikian, pembelajaran daring juga memberikan dampak negatif bagi peserta didik maupun orang tua. Berdasarkan permasalahan di atas, tujuan dari penulisan artikel ini adalah untuk mendeskripsikan mengenai kebijakan pendidikan di Indonesia pada masa pandemi covid- 
19 beserta dampaknya dan diharapkan dapat memberikan solusi bagi pendidik, peserta didik dan orang tua dalam menghadapi kebijakan tersebut.

\section{METODE PENELITIAN}

Metode penelitian merupakan cara berfikir, berbuat yang dipersiapkan dengan baik untuk melakukan suatu penelitian dan untuk mencapai suatu tujuan dalam penelitian. Metode penelitian ini merupakan pemandu peneliti mengenai urutan penelitian yang dilakukan. Dalam metode penelitian ini membahas bagaimana suatu penilitian dilakukan secara berurutan, yaitu menggunakan alat apa dan prosedur bagaimana suatu penelitian ini dilaksanakan.

Dalam penelitian ini model yang digunakan adalah analisis konten dan wawancara, yang mana analisis konten tersebut dilakukan dengan maksud untuk menemukan pesan simbolik dalam sebuah buku atau karya tulis seseorang. Disamping itu, hasil wawancara juga dimaksudkan untuk menemukan jawaban terkait dampak dari adanya pembelajaran daring bagi orang tua maupun anak baik dari segi psikologi dan ekonomi.

Sedangkan teknik penelitian yang digunakan pada penelitian ini adalah dengan menggunakan teknik berupa penelitian kepustakaan/ studi literatur, hal ini dilakukan karena data-data yang diteliti juga sudah tertulis dalam jurnal-jurnal terdahulu. Disamping itu peneliti juga mengumpulkan informasi dari berbagai sumber melalui wawancara, yang mana responden tersebut adalah orang tua dari siswa mulai dari jenjang SD sampai dengan SMA. Adapun instrumen wawancara adalah sebagai berikut:

1. Apa saja kesulitan saat pembelajaran daring?

2. Apakah guru memberikan materi dan petunjuk belajar kepada siswa?

3. Selama ini pembelajaran daring menggunakan media apa saja?

4. Apa dampak negatif dan positif yang dirasakan dari adanya pembelajaran daring?

5. Dan apakah mempengaruhi ekonomi keluarga?

Dalam sebuah penelitian terdapat juga prosedur penelitian yaitu suatu langkah/ ketentuan/ proses yang dilakukan oleh peneliti. Adapun prosedur penelitian adalah sebagai berikut:

1. Pendahuluan, yaitu tahap awal dimana peneliti mencari informasi terkait judul penelitian

2. Penyusunan rancangan penelitian, yaitu meliputi metode penelitian yang akan digunakan 
3. Pelaksanaan penelitian, yaitu tahap pencarian informasi dengan mencari data melalui media cetak, media elektronik, ataupun dengan wawancara terkait dengan judul yang akan diteliti

4. Penulisan hasil/ laporan, yaitu tahap terakhir dalam penelitian dengan membuat laporan tertulis.

Adapun analisis data merupakan sebuah proses untuk membuat pemodelan data yang dimaksudkan untuk menemukan informasi yang bermanfaat sehingga dapat memberikan petunjuk dan mempermudah peneliti untuk memahami isi data tersebut. Dalam penelitian ini digunakan analisis data kualitatif, yang mana diharapkan akan memperoleh gambaran terkait kebijakan pendidikan di Indonesia pada masa pandemi covid-19.

\section{HASIL DAN PEMBAHASAN}

Belajar yang dilaksanakan dari rumah ditetapkan melalui kebijakan yang dikeluarkan oleh Kemdikbud Republik Indonesia melalui Surat Edaran Kemdikbud No. 4 Tahun 2020 tentang pelaksanaan pendidikan pada masa darurat covid-19. Dari kebijakan tersebut kemudian memberikan dampak pada proses pembelajaran yang ada di sekolah, terutama untuk peserta didik, guru, maupun orang tua. Kebijakan yang dilaksanakan secara daring/ jarah jauh mendapatkan berbagai respon dari publik. Meskipun tidak ideal, pembelajaran secara daring merupakan satu-satunya kebijakan yang memungkinkan bahwa proses pembelajaran tetap dapat dilakukan di masa pendemi covid-19.

Belajar secara daring menuntut peran guru untuk mengevaluasi efektifitas dan disesuaikan dengan kebutuhan belajar peserta didik. Hal tersebut sangat penting dilakukan karena untuk tetap memenuhi aspek spiritual, sosial, pengetahuan, dan keterampilan. Mengingat bahwa perubahan pembelajaran yang semula tatap muka menjadi tatap maya secara tidak langsung memberikan pengaruh pada daya serap peserta didik.

Selama peserta didik melakukan pembelajaran dan kegiatan dari rumah, orang tua memiliki peran sebagai pendamping, fasilitator, motivator, dan melaporkan kegiatan yang peserta didik lakukan kepada guru sebagai bagian assessment perkembangan peserta didik. Guru juga harus sering memantau peserta didik melalui orang tua yang melakukan kegiatan belajar dari rumah.

Hasil penelitian lain juga menunjukkan bahwa kebijakan pendidikan pada masa pandemi covid-19 dilaksanakan dengan metode pembelajaran online (daring) dan pembelajaran luring yang dilaksanakan dengan protokol kesehatan yang ketat, serta adanya pembagian waktu peserta didik untuk datang ke Sekolah. Namun, hal tersebut dapat 
terlaksana sebelum adanya penerapan level 4 untuk daerah di Jawa Timur khususnya di Kabupaten Ponorogo.

Hasil penelitian yang peneliti lakukan di Ponorogo menunjukkan bahwa pada tanggal 24 Agustus 2021, dikeluarkannya SE Keputusan Bupati Ponorogo Nomor: 188.45/1045/405.01.3/2021 tentang Pemberlakukan Pembatasan Kegiatan Masyarakat Level 4 Corona Virus Disease 2019 di Kabupaten Ponorogo, yang memutuskan bahwa kegiatan belajar mengajar di satuan pendidikan dilakukan secara daring dan pelaksanaan kegiatan pada sekot non esensial diberlakukan 100\% Work From Home (WFH).

Meskipun demikian, masih ada beberapa sekolah yang tetap melakukan pembelajaran secara luring dan tidak sepenuhnya daring. Kebijakan-kebijakan tersebut dapat berubah-ubah seiring berjalannya waktu serta melihat kondisi di Indonesia terkait penyebaran virus corona ini. Apabila penyebaran virus covid-19 merajalela maka kebijakan yang dikeluarkan pastinya akan menjadi semakin ketat, akan tetapi jika penyebarannya sudah mulai menurun maka kebijakan yang dikeluarkannya pun juga sedikit dilonggarkan.

Dapat dilihat juga pada saat ini, bahwa hasil assessment Kementerian Kesehatan Republik Indonesia pada tanggal 23 September 2021, Kabupaten Ponorogo bersama 24 Kabupaten lain di Jawa Timur sudah ditetapkan sebagai daerah PPKM (Pemberlakukan Pembatasan Kegiatan Masyarakat) pada level 1, yang mana hal tersebut membuat masyarakat merasa lebih bebas dan tidak tertekan seperti pada saat PPKM level 4. Sama halnya dengan kegiatan belajar mengajar yang sudah diperbolehkan dilaksanakan secara tatap muka, akan tetapi dengan protokol kesehatan yang ketat dan masih belum diperbolehkan dilakukan secara tatap muka. Misalnya dalam seminggu untuk kegiatan belajar mengajar secara tatap muka dilaksanakan selama 2 hari sekali, yang sisanya adalah untuk pembelajaran jarak jauh atau daring.

Meskipun demikian, dampak dari pembelajaran daring ini sangat mempengaruhi siswa dan orang tua baik dari segi ekonomi dan psikologi. Berdasarkan hasil wawancara yang peneliti lakukan kepada 9 narasumber dari jenjang SD sampai dengan SLTA menunjukkan bahwa kesulitan yang dialami para anak dan orang tua saat pembelajaran daring yaitu kurangnya pemahaman dari materi pelajaran yang diberikan, yang menyebabkan anak menjadi kurang maksimal dalam belajar. Sinyal yang sulit juga menjadi permasalahan dalam pembelajaran daring ini. Walaupun juga banyak dari guru yang memberikan penjelasan melalui video tetap saja memahami pelajarannya tidak semudah saat pembelajaran secara tatap muka. Ada juga dari orang tua siswa yang 
kewalahan mengajari anaknya, karena dari pihak guru sendiri hanya memberikan materi dan tugas yang terkadang tanpa diberikan penjelasan.

Diberbagai Sekolah, pembelajaran daring ini lebih banyak menggunakan media whatsapp, akan tetapi ada beberapa yang menggunakan google classrom dan juga $e$ learning. Pembelajaran daring memberikan dampak yang cukup signifikan baik dampak negatif, positif dan dari segi ekonomi keluarga maupun psikologi anak. Dampak negatif dari adanya pembelajaran jarak jauh ini yaitu menguras waktu dan tenaga orang tua untuk mengajari anaknya, apalagi jika anak tersebut masih duduk di bangku sekolah dasar. Orang tua mengalami stress karena banyaknya tugas yang diberikan dan anak sendiri kurang optimal dalam belajar. Anak menjadi malas dan cepat bosan karena tidak ada teman saat pembelajaran dan terlalu sering menatap layar handphone maupun laptop juga dapat merusak mata.

Sedangkan dampak positif dari pembelajaran jarak jauh ini yaitu, orang tua sebenarnya menjadi lebih dekat dengan anak, memiliki waktu bercengkerama lebih banyak dengan anak, orang tua bisa lebih mengawasi anak dan anak itu sendiri bisa membantu orang tuanya. Jika dilihat dari sisi ekonomi, memang banyak sangat berdampak bagi perekonomian keluarga, yaitu pembelian kuota setiap bulannya, terkadang belum sampai satu bulan kuota internet sudah habis.

Hal tersebut yang menyebabkan pemborosan dalam ekonomi keluarga, yang seharusnya hemat menjadi boros karena adanya pembelajaran daring, walaupun ada beberapa orang tua yang memasang wifi di rumahnya tapi banyak dari orang tua siswa yang menggunakan paket internet biasa (kuota). Disamping itu, dari sisi psikis anak, mengikuti pembelajaran dari rumah membuat mereka tidak merasakan tekanan dari teman sebaya seperti bullying yang biasa mereka alami saat pembelajaran luring.

Kebijakan yang dikeluarkan oleh Kemdikbud Republik Indonesia melalui Surat Edaran Kemdikbud No. 4 Tahun 2020 tentang pelaksanaan pendidikan pada masa darurat covid-19 dan juga Surat Edaran Keputusan Bupati Ponorogo Nomor: 188.45/1045/405.01.3/2021 tentang Pemberlakukan Pembatasan Kegiatan Masyarakat Level 4 Corona Virus Disease 2019 di Ponorogo mengandung isi yang sama, yaitu mengenai proses pembelajaran yang harus dilaksanakan secara online/ jarak jauh. Yang mana kegiatan tersebut sangat memberikan dampak bagi pendidik, peserta didik, dan orang tua, baik dampak positif maupun dampak negatif. Akan tetapi, pembelajaran jarak jauh ini merupakan satu-satunya solusi agar proses kegiatan belajar mengajar tetap bisa dilaksanakan. Penetapan kebijakan pendidikan mengenai kegiatan pembelajaran tersebut 
dapat berubah-ubah, melihat bagaimana situasi dan kondisi dari penyebaran virus covid19. Meskipun dari pemerintah sudah menetapkan Surat Edaran terkait kebijakan pembelajaran pada masa pandemi covid-19, ada beberapa pihak sekolah yang masih memiliki kebijakan sendiri, sekolah yang berada di daerah pelosok dan jauh dari perkotaan masih ada yang menerapkan pembelajaran secara tatap muka dengan tetap ada batasan serta mematuhi protokol kesehatan yang ketat.

Dari hasil penelitian tersebut dapat diketahui bahwa kebijakan yang ada di Indonesia selalu berubah-ubah menyesuaikan dengan kondisi yang sedang terjadi. Oleh karena itu, sebelum keputusan/ kebijakan tersebut dikeluarkan oleh pemerintah banyak pertimbangan yang harus dilakukan, tidak semata-mata mengeluarkan kebijakan, akan tetapi melihat dari berbagai sudut pandang.

Lahirnya keputusan-keputusan tersebut merupakan suatu bentuk perubahan pada sistem pendidikan di Indonesia dikarenakan adanya wabah menular yaitu virus covid-19, dimana virus tersebut akan sangat mudah menular jika banyak kerumunan, oleh karena itu, kebijakan pada sistem pendidikan dirubah sedemikian rupa untuk mencegah penyebaran virus tersebut, meskipun banyak dari publik yang merasa keputusan tersebut memberatkan bagi mereka akan tetapi kebijakan tersebut adalah satu-satunya kebijakan yang mampu menekan penambahan penyebaran virus covid-19.

Pada dasarnya kebijakan pendidikan di masa pandemi-covid-19 dibuat merata di seluruh Indonesia, meskipun dari berbagai daerah juga memiliki keputusan sendiri dengan melihat kondisi di wilayahnya masing-masing. Akan tetapi pada intinya keputusan tersebut sama, yaitu sama-sama untuk menekan angka penyebaran virus covid-19. Baik penelitian terdahulu dan penelitian yang peneliti lakukan saat ini tidak banyak memiliki perbedaan, dikarenakan kondisi di Indonesia yang saat ini masih belum benar-benar bersih dari virus, proses pembelajaran juga masih belum bisa dilakukan secara tatap muka sepenuhnya, meskipun pada saat ini sudah banyak diadakan vaksinasi bagi masyarakat khususnya para pelajar dan tenaga kependidikan di Indonesia. Pembelajaran tetap dapat dilaksanakan secara tatap muka dengan skala yang kecil dan tetap mematuhi protokol kesehatan yang ketat.

Adanya wabah pandemi virus covid-19 ini menjadi evaluasi bagi sistem pendidikan di Indonesia, dimana kegiatan-kegiatan khususnya dalam dunia pendidikan mengalami perubahan yang sangat signifikan. Diperlukan adanya rencana untuk sistem pendidikan dalam tahap berikutnya, jika virus covid-19 masih belum sepenuhnya hilang dari muka bumi. Program vaksinasi yang sudah terlaksana harus tetap dilaksanakan secara 
sepenuhnya bagi seluruh masyarakat di Indonesia, hal tersebut menjadi sebuah usaha untuk mengurangi penyebaran virus corona dan jika seluruh masyarakat Indonesia sudah melakukan vaksinasi secara keseluruhan dapat memungkinkan bahwa proses pembelajaran dapat dilakukan seperti sedia kala yaitu dengan tatap muka di sekolah masing-masing.

\section{SIMPULAN}

Dari artikel diatas dapat disimpulkan bahwa proses pendidikan pada masa pandemi covid-19 mengalami perubahan, dimana permerintah membuat kebijakan bahwa proses pembelajaran yang semula dilakukan secara tatap muka di Sekolah menjadi tatap maya/ pembelajaran secara daring (jarak jauh). Kebijakan yang dibuat pemerintah tersebut masih menjadi satu-satunya solusi agar proses pembelajaran tetap dapat dilaksanakan.

Namun, kebijakan pembelajaran secara daring yang ditetapkan oleh pemerintah memberikan dampak yang signifikan bagi peserta didik, pendidik, maupun orang tua. Hal tersebut dikarenakan kurangnya persiapan dari sekolah, pendidik, dan peserta didik itu sendiri. Disamping itu, tidak semua peserta didik bisa beradaptasi secara cepat dengan perubahan proses pembelajaran menjadi daring seperti ini. Selain itu pembelajaran secara daring juga sangat berdampak bagi orang tua, yang mana para orang tua harus ikut serta dalam mendampingi anaknya apalagi jika masih pada jenjang sekolah dasar yang membutuhkan bimbingan. Secara ekonomipun orang tua juga kesulitan dikarenakan penggunaan kuota internet yang cukup banyak dan bahkan jaringan internetnya pun terkadang juga bermasalah. Banyak dari peserta didik yang mengeluh dengan adanya pembelajaran daring, dikarenakan mereka menjadi sulit memahami materi yang diberikan oleh guru dan ditambah lagi banyaknya tugas-tugas yang diberikan.

Dengan demikian, kebijakan pendidikan yang ditetapkan oleh pemerintah masih banyak kekurangan dan belum bisa dikatakan efektif. Oleh karena itu, diperlukan adanya evaluasi serta pembenahan pada agar proses pembejalaran dapat terlaksana dengan lebih baik dan bisa dikatakan efektif. Salah satunya adalah dengan memberikan bimbingan kepada pendidik mengenai penguasan teknologi pada proses pembelajaran pada saat ini. Pendidik juga harus memberikan motivasi kepada peserta didik maupun orang tua, agar mereka lebih bersemangat dalam mengikuti pembelajaran meskipun masih dalam keadaan pandemi covid-19. 


\section{SARAN}

Dari hasil penelitian di atas, saran yang dapat diberikan , yaitu (1) hasil penelitian ini dapat dijadikan referensi bagi pendidik dan peserta didik dalam melaksanakan pembelajaran secara daring dan bagi orang tua dapat menjadi pendukung pembelajaran daring, (2) pembelajaran daring ini hendaknya menjadi perhatian dan pendidik mencari solusi yang tepat dan inovatif agar proses pembelajaran tetap berjalan dengan baik meskipun dalam keadaan tatap maya. Peneliti lain disarankan untuk melakukan penelitian lanjutan dengan tema yang sama di daerah yang lain.

\section{DAFTAR PUSTAKA}

Abidin, Z., Hudaya, A., \& Anjani, D. (2020). Efektivitas pembelajaran jarak jauh pada masa pandemi covid-19. ... Development Journal of ... https://journal.lppmunindra.ac.id/index.php/RDJE/article/view/7659

Ameli, A., Hasanah, U., Rahman, H., \& ... (2020). Analisis keefektifan pembelajaran online di masa pandemi COVID-19. In ...: Jurnal Pendidikan .... ummaspul.ejournal.id. https://ummaspul.e-journal.id/MGR/article/download/559/313

Anugrahana, A. (2020). Hambatan, solusi dan harapan: pembelajaran daring selama masa pandemi covid-19 oleh guru sekolah dasar. Scholaria: Jurnal Pendidikan Dan Kebudayaan. https://ejournal.uksw.edu/scholaria/article/view/4033

Astini, N. K. S. (2020). Pemanfaatan teknologi informasi dalam pembelajaran tingkat sekolah dasar pada masa pandemi covid-19. Lampuhyang. http://e-journal.stkipamlapura.ac.id/index.php/jurnallampuhyang/article/view/194

Astini, N. K. S. (2020). Tantangan Dan Peluang Pemanfaatan Teknologi Informasi Dalam Pembelajaran Online Masa Covid-19. Cetta: Jurnal Ilmu Pendidikan. http://jayapanguspress.penerbit.org/index.php/cetta/article/view/452

Ginting, M. S., Lastriani, U., Mahmuzah, R., Kurnia, H., \& Aklimawati, A. (2021). The Analysis of Learning Outcomes through Problem-Based Learning Model Approach On Circle Materials. JURNAL SERAMBI ILMU, 22(1), 110-125.

Haryadi, R., \& Selviani, F. (2021). PROBLEMATIKA PEMBELAJARAN DARING DI MASA PANDEMI COVID-19. Academy of Education Journal, 12(2), 254-261. https://doi.org/10.47200/aoej.v12i2.447

Herliandry, Luh Devi, Nurhasanah, dkk. 2020. "Pembelajaran pada Masa Pandemi Covid19". Jurnal Teknologi Pendidikan Vol 22, No. 1.

Joharudin, A., Septiadi, M. A., Maharani, S., \& ... (2020). panic syndrom covid-19: penekanan terhadap kebijakan yang diberikan. Jurnal http://perspektif.uinsgd.ac.id/index.php/JP/article/view/63

Juliya, Mira, dkk. 2021. "Analisis Problematika Pembelajaran Daring dan Pengaruhnya terhadap Motivasi Belajar Siswa”. GENTA MULIA”, Vol XII No. 1.

Khasanah, D., Pramudibyanto, H., \& ... (2020). Pendidikan dalam masa pandemi covid-19. Jurnal .... http://sinestesia.pustaka.my.id/journal/article/view/44 
Kurnia, H., Sriyogani, I. A., \& Nuryati, N. (2021). Implementasi Nilai-Nilai Pancasila dalam Food And Beverage Departemen di Restoran Hotel New Saphir Yogyakarta. Jurnal Basicedu, 5(5), 4127-4137.

Mansyur, Abd. Rahim. 2020. "Dampak COVID-19 terhadap Dinamika Pembelajaran di Indonesia". Educational dan Learning Journal, Vol 1 No 2.

Marhaban, M. (2021, September 25). Times Indonesia. Retrieved from Peristiwa Daerah: https://amp.timesindonesia.co.id/read/news/372242/ponorogo-turun-ke-ppkm-level1-masyarakat-diminta-tetap-taat-prokes

Muyasaroh. 2020. "Dampak Positif dan Negatif Metode Belajar Daring Bagi Orang Tua". "Jurnal Pendidikan Islam, Vol 13 No. 01".

Pohan, Albert Efendi. 2020. Konsep pembelajaran daring berbasis pendekatan ilmiah. CV Samu Untung.

Putria, H., Maula, L. H., \& Uswatun, D. A. (2020). Analisis proses pembelajaran dalam jaringan (daring) masa pandemi covid-19 pada guru sekolah dasar. Jurnal Basicedu, 4(4), 861-870.

Sadikin, Ali, dkk. 2020. "Pembelajaran Daring di Tengah Wabah Covid-19". Jurnal Ilmiah Pendidikan Biologi, Vol 6 No. 02.

Saleh, Ahmad Muzawir. 2020. "Problematika kebijakan pendidikan di tengah pandemi dan dampaknya terhadap proses pembelaaran di Indonesia", Universitas Islam Negeri Alauddin. Makassar.

Santosa, Ari Budi. 2020. "Potret Pendidikan di tahun Pandemi: Dampak Covid-19 terhadap Disparitas Pendidikan di Indonesia". Departemen Hubungan Internasional CSIS Commentaries DMRU-079-ID.

Sari, Widya, Muhammad, Andi, dkk. 2020. “Analisis Kebijakan Terkait Implementasi Pembelajaran Jarak Jauh pada Masa Darurat Covid 19”, Jurnal Mappesona.,

Septiani, Eka. 2020. "Penggunaan Media Pembelajaran Secara Daring terhadap Pemahaman Belajar Mahasiswa", Prosiding Seminar Nasional Pascasarjana Universitas Negeri Jakarta.

Sudarsana, I Ketut, dkk. 2020. Covid-19 (Perspektif pendidikan). Denpasar: Yayasan Kita Menulis.

Surat Edaran Nomor 4 Tahun 2020 Tentang Pelaksanaan Kebijakan Pendidikan dalam Masa Darurat Penyebaran Corona Virus Disease (covid- 19 ).

Surat Edaran Nomor 15 Tahun 2020 Tentang Pedoman Penyelenggaraan Belajar Dari Rumah Dalam Masa Darurat Penyebaran Corona Virus Desease (Covid-19).

Surat Edaran Keputusan Bupati Ponorogo Nomor: 188.45/1045/405.01.3/2021 tentang Pemberlakukan Pembatasan Kegiatan Masyarakat Level 4 Corona Virus Disease 2019.

Wijayanti, M., Yunita, T., \& Dharmanto, A. (2020). Pembelajaran perguruan tinggi dalam jaringan (daring) masa pandemi covid-19. Jurnal Kajian Ilmiah. http://36.91.136.44/index.php/JKI/article/view/268

Yulianingsih, W., Suhanadji, S., Nugroho, R., \& ... (2020). Keterlibatan Orangtua dalam Pendampingan Belajar Anak selama Masa Pandemi Covid-19. Jurnal Obsesi: Jurnal .... https://obsesi.or.id/index.php/obsesi/article/view/740 